University for Business and Technology in Kosovo

UBT Knowledge Center

UBT International Conference

2015 UBT International Conference

Nov 7th, 9:00 AM - 5:00 PM

\title{
Metaphysical dialogue between philosophy and music in ancient Greek
}

Sunaj Raimi

University for Business and Technology, sunaj_raimi@hotmail.com

Follow this and additional works at: https://knowledgecenter.ubt-uni.net/conference

Part of the Law Commons

\section{Recommended Citation}

Raimi, Sunaj, "Metaphysical dialogue between philosophy and music in ancient Greek" (2015). UBT International Conference. 4.

https://knowledgecenter.ubt-uni.net/conference/2015/all-events/4

This Event is brought to you for free and open access by the Publication and Journals at UBT Knowledge Center. It has been accepted for inclusion in UBT International Conference by an authorized administrator of UBT Knowledge Center. For more information, please contact knowledge.center@ubt-uni.net. 


\title{
Metaphysical dialogue between philosophy and music in ancient Greek
}

\author{
Sunaj Raimi \\ UBT - Higher Education Institution \\ sunaj_raimi@hotmail.com
}

\begin{abstract}
The main idea of this scientific lecture will be a comparative analysis of the essential similarities between the philosophical culture and musical art in ancient Greece. The processing of this study will remain in different historical periods where philosophy, known as more sophisticated technique of the human thought together with the musical creativity as the art of the Muses in ontological aspect, will be sublimated in a common denominator. As it's known, the substance of music as spiritual human creativity has always been and remains - an "intimate" matter of philosophy, just as philosophy has always remained an eternally pleasant music of the human mind. In this context, will also speak on why philosophy and philosophers from all known forms of art until then rated the musical art as one of the most important creativity in human's life.
\end{abstract}

Keywords: antiques, phylosophy, music, ontology corespondence, artistic hierarchy, helenical assessment etc.

\section{Introduction}

The main aim of this study will be the comparative analysis of essential similarities between philosophical culture from one side and of musical art in the ancient Greece from another side. Current emphasis of this study will stand over different historical periods, where philosophy like a more sophisticated technique of people's thoughts, together with the musical creativity like art itself is in the metaphy sic aspect will be commonly sublimated together. As such, the substances of music like spiritual creativity of a man has always been and has remained ones 'confidential' issue of philosophy, like the philosophy that has remained forever a pleasant music of human mentality! In this context, we will also talk about why philosophy and philosophers from all the artistic known forms of that time, the musical art they had appreciated like the most important creativity in the human social life. It is known that like the philosophy that aimed on formulating the moral character through deep analy sis and smart wisdoms, this music has made through harmonious tunes and relevant instruments. For this reason Greek philosophers appreciated music very much, being thus convinced that the music like spiritual pleasure shows a strange counterweight, a true balance between the phy sical activity and mental activity of people. This way the distinguished philosopher Plato considered that music enables to the person to soften the wildered feelings and roughness, while Pythagoras confirmed that music refreshes and sharpens the brain, giving thus the penetration power in contemplating.

It is known that one of the specific duties of philosophy was that the human be taught to become cautious, non-concerned and happy. But this duty has also the music! But, since philosophy aims to achieve through different theoretical and practical doctrine, music made that through special musical shapes, songs and special instruments. From all this that we said above it is clear that the position of music in artistic hierarchy of the ancient Greece was in the roof of the pyramid. It amazes the way with whom the Greeks being so much philosophically cultivated and applied the music in their private life socially and culturally. Greek philosophers appreciated so much the music, believing that like a spiritual pleasant it represents a counterweight, strange balance between physical and mental activity of humans. Thus, while Plato considered that music enables someone soften the wild feelings and roughness, Py thagoras has the conviction that the music refreshes the brain and sharpens it givinghim depth powers in contemplating.

Besides all this, the issue of what role has music in Greek town-states, respectively what was the status of it alongside other artistic disciplines, the best reflects us Plato when the order and prosperity 
of state is conditioned with it that how good is the music there and how the citizens are educated with music. To become the music on top of art, also has contributed the aspiration of Helens to that which is called the integration of personality, this epithet that is given only those that besides solid mental, physic and ethics features it has also a musical sense. Of course this it wasn't casually like this. These divine and philosophic attributes of ideal man (stronger, smart, good, brave) actually are closed related with music for many reasons. First attribute, power, achieved through training, where is trained in accompanied by rhythmic music; wisdom is achieved with philosophy, which when is lectured or taught with music it becomes easier and cleared for understanding, goodness is earned through good music, Apollo music which ennoble the human feelings, creating a moral personality; and in the end the courage which is achieved by listening and singing patriotic and heroic songs. The fact that in report with other arts in Greece the diadem always it holds the music, it can be proved with that all competitions of famous, by beginning from bizarre sport disciplines and to the beautiful arts, the beginning, development and the end they had exactly from music.

\section{Similar development phases of philosophy and the ancient mus ic}

When it's about the metaphysic dialogue between philosophy and music through different functions that they had in the life of Helens, I think that this more faithfully can be reflected in the same evolutionary path of philosophy and of musical art through the history. With other words, if we know better the development history of Greek philosophy and analogously with this even the own history of the development of Greek music then easily we will understand that development path of these two (philosophy and music) through the ancient history it's almost the same. This means that ups and downs that philosophy has experienced through its life in antique, it has the music. So for e.g. like the Greek music started from the first phase of its development (760-600) it's characterized with the primitive practical music and with instruments and poor musical shapes like the philosophy of this phase characterized with vulgar conceptions and naives philosophical doctrines. This phase it's in the sign of establishment and formation of these two social activities. In the second phase of development (600-450) which for the music shows a genuine zenith it comes to discovery of some new instruments and new musical shapes, where it made the broader establishment of music of one crucial case in the educational process of Ancient Greece. Same with this, the philosophy of this phase it has achieved the culmination, with that that now in this dimension are showed new philosophic conceptions as the first philosophic schools, where philosophy together with music are made so important subjects in the general educational process of Greek that are counted like two main columns in building of personality. In this phase it comes also first, for clarification and definition of music as phenomenon socio cultural, but also as specific artistic discipline. Here in deed there are made philosophic foundations of music of ancient Greece. Like philosophy that has for purpose the building of moral personality through philosophic interpretation and depth analy sis so the music this has made through harmonic melodies of relevant instruments. As a result of this teleological alliance moral and educational of music with philosophy is tragedy which can't survive without one of these two elements. As the end, the main function of tragedy stands exactly in the chance that to indicate educationally in the psyche and ethos of public. Through this, the text of tragedy that shows philosophical element realized moral cleansing of psyche from the ugly thoughts, while the melody of tragedy which shows the musical element realized moral transformation anti generous lusts. The music of the third phase (440-300) same like the philosophy characterized with last stoic attempts for further maintenance in life of all values which like that are weighed in previous periods. This has proved big philosophers Plato and Aristotle which lived exactly in this period of time and which by acting in their philosophical schools and in the public opinion of that time (that we will talk later) that has lost all the opportunities, ways and tools in attempt that philosophy and music to keep the main aim of them, so education socio-moral of citizens, that shows in the creation of good people and for the good state. In reality all this development phase passed into the emblem of these two colossus of the philosophy of Greece, for which later will obey that these where worthiest philosophers that indicated in setting of philosophical foundations of psycho-moral role and socio-educational of music in ancient Greece. 


\section{Musical formation like argument for the completed education}

Yet by the time of remarkable philosophical schools, along with the philosophy of music they became so important subjects in the overall process of Helad educational that counted as two fundamental pillars for the construction of human personality. In particular highlighted specific function of music, which should help achieve ideal health of body and soul.

For this reason, of all the arts of the time, the Greek philosophers mostly appreciated the music, which for the reasons mentioned in the educational plans of schools then these philosophers, was installed with special care. This old art Hellenes considered as the roof of the building on a complete personality, because they were convinced that without this component other features were incomplete, deficient. A man who throughout his education has failed to learn to sing or execute any instrument, Greeks reckoned as mediocre or person not sufficiently educated! Thus, some of the glorious personalities of Greek history (e.g. Temistoklo) felt humiliated publicly because of lack of proper musical training. And because of this lack of musical training, prominent people of that time, often after gaining important functions, private lessons to follow outstanding musicians to learn any instrument execution.

Music was privileged to Greek art also because of its role of moral, emotional. As with the help of special melodies activated moods of people working until they phy sical or mental work; with its help unmaintained military morale; sublimated, excited and emotions of the public (as in a play, concert or scaffold); entertained the people rejoice at weddings and other fun date, and so on. In other words, so people anneal emotional structure. This proves the A.Kuintiliani scholar, who in the work of famous "The music" Book II, chapter IV, speaking about how the brand can affect the overall music in human life wrote the music encourages and facilitates military bravery of long marches, facilitates navigation and heavy works made with hands, because of the sufferings appear as comforting. Greeks treated music as exclusive art from the cause that she was the only artistic discipline that was present in all the most important moments of human life. And starting from the moment of birth of the man, which was marked with music, special moments (like birthdays, graduation, employment, weddings, etc.), which were always filled with music and fun relatives and friends, to the the day of death, when the man buried in the music suite painful.

They even believed that music has a powerful impact on the animal emotional world, for what reason and shepherds pleasant flute melody of cattle grazed, watered rivers and home. The centrality of music in art of ancient Greece, also confirmed that if the artist musician did not meet the standards of any manifestation musical general public had a right to a sign of frustration and revolt outrageous, ask him musician punished publicly. While this does not happen in other arts events (like the oratory, acting, sculpture, poetry, etc.), where the artist unsuccessful only public and despised. For this phenomenon proves sentence shy of the Greeks he pronounced traitors, rebels, conspirators and their children, who punish the communication life musical community, and he occupied in this way the right to education and music education and the transmission of musical events. However, this approach represented a very severe punishment, for thus it deprives the individual of natural law - the possibility that he be dignified and respected citizens in the polis. From this it becomes clear why the ancient Greeks appreciated music most from all other arts. Moreover it became subject and ambition of the two most basic social activities, family education and school education. The former music needed due to be carried out socio-p sy cho-moral emotions, while the latter served to drill the technical to the Greek new, this later can distinguish good music from it not good, so useful music by damaging.

\section{Philos ophical Interpretation of instruments}

From all these considerations, our become clear that the Hellenes of the old with the help of their wisdom (philosophy) and large experience of life they had collected during cruises numerous in the Mediterranean, really knew that all instruments be ' understand, interpret and apply the most appropriate ways. It is also a testimony to the genius of the people, where musical instruments were used as preparations for the maintenance of psy chophy sical balance and moral cultivation of mentality in society. But this development Breaking cultural events - artistic Helade was not the game of the case, because "all artists and holders of culture at that time were set tasks through the art of idealized life, where later it would be realized and placed in the highest degree of perfection "(Novakovic 1976, 
fq.34). The generous collection instrument of the Greeks of old represented a fruitful background to devise quite philosophical research that would later produce philosophical explanations for moral and educational functions and psycho-social music. Usually, stringed instruments serve for personal pleasure, for concerts, for private inaugurations, listening to poetry and philosophy, or simply to rest. While serving spiritual instruments for blissful moments, for religious rites, for military exercises and attacks, for sale as well as the emergence of drama. On the other hand, striking instruments are used for maintenance of tact and rhythm of music as to stringed instruments, as well as those breathes that obey in that collection instrument in Greece Old musical was philosophical basis and moral and educational role and Psy chosocial music depended on the instruments, it is enough to stop the analy sis of the then two main instruments: the instrument stringed instrument with a mild grease and (Aulosin). In ancient Greece lyra (or guitar) was synony mous to measure emotional music, but (aulosi), was synonymous with emotional music pathetic. These two instruments ancient Greeks treated with special care philosophy, since until (lyra) was attributable to the God Apollo, whom the Greeks reckoned as a symbol of intellectual enlightenment and moral (aulosi) was attributable to the deity Diony sius, which the Greeks honored as sy mbol of euphoric celebrations and merriment. This means that the music identified with the function of lubricant metaphy sical philosophy, which aims wisdom and moral lighting. Meanwhile (aulosit) music identified with passion and exaltation that is contrary to the ideal primordial philosophy - intellectual maturity and moral stability.

Greek philosophical spirit was present in all segments of society ranging from the most diverse activities, crafts, and sciences to the arts of ancient Greece, but its full expression found exactly to the music. The reason is there that the Greeks were convinced that music ennobles the soul, calms feelings, provides power, versatility, dexterity, getting made, pride, dignity, etc., but it could also discourage, laziness, indolence, inertia, clumsiness, negligent, apathy, rudeness etc. (Ismail 2000, pg.55). So precisely herein lays the answer to why the ancient Greeks so highly prized apolonic grease and music, while the music marginalize and (aulosin). They knew that music aulosit of troubling feelings, while the lubricant calms them. That's what the legend according to which the musical duel between Apollo, competing with rival grease and Marsiasit, who opposed him with aulos, Apollo prevails harmonious with its grease. Victory of Apollo, who was also at the same time God oratory, figuratively reflects the victory of philosophy (wisdom) to sensory (passion). Quite characteristic is another myth, which metaphorically shows how Athena, goddess of wisdom (symbol and allegory of philosophy) had thrown (aulosin) by cursed anyone who would execute it. This clearly demonstrates that "philosophical cult" of the Greeks had set itself the cultural heritage of their art. And that it had great importance for the life of the Hellenes then, because music was seen as a skill at the time of the Gods, which had featured miraculous supernatural influence.

More interesting it is to break down the attitude of Plutarch, one of the last great representatives of Greek philosophy and culture, which is talking about the advantages and disadvantages of the two most important instruments of Greek instruments (ly ra and aulosi) actually us reveals "philosophical wire" of lubricant. According to him those who can play simultaneously instrumented grease and sing, i.e. even speak (which represents a potential op portunity for the man to speak philosophy). And those who have not blowing in aulos such opportunities, because during this voice and their speech was busy. This shows that lipids (her music), not only did not prevent the man to deal with philosophy (because he could also execute both speak), but also helped him to have the soul calm, relaxed and harmonious in relation to any philosophy. Therefore in this context it is understood Plato's suggestion that the perfect state "can be used only lipids and guitar." (Plato 1980, fq.132). During this analy sis of ours was dichotomist attempt to explain why ly ra as the main representative of stringed instruments was estimated that as aulosi, who was the leading representative of spiritual instruments. So it can say that this practice was a result of the Greek mentality and mindset for a harmonious society, which actually aimed idealized life of the Gods in Olympus.

\section{References}

1. Platoni, (1980), Shteti, Rilindja, Prishtinë.

2. Novaković, Aleksandar, (1976), Zvuci sa Parnasa, Sportska knjiga, Beograd.

3. Ismaili, Zijadin, (2000), Muzika nëpër shekuj, Shkup.

4. Plutarku. (1980), Jetë njerëzish të shquar të lashtësisë, Naim Frashëri, Tiranë.

5. Šefold, Karl, (1973), Klasična Grčka, Bratstvo-Jedinstvo, Novi Sad. 
6. Saks, Kurt, (1980), Muzika starog sveta - univerzitet umetnosti, Beograd.

7. Marković, Zvonimir, (1972), Muzički Instrumenti, Muzička Naklada, Zagreb

8. Lučano, Alberti, (1974), Muzika kroz vekove, Vuk Karadžić, Beograd.

9. Muzička Enciklopedija,(1974), I-II tom, Gr-Op, Jugoslovenski leksikografski zavod, Zagreb.

10. Heveler, Kasper, (1967), Muzički leksikon. Matica Srpska, Subotica.

11. Hauzer, Arnold, (1966), Socijalna istorija umetnosti i kniževnosti. I tom, Kultura, Beograd.

12. Hanslick, Eduard, (1977), O muzički ljepom. BIGZ, Beograd.

13. Aristoteli, (1978), Politika. Rilindja, Prishtinë.

14. Andreis, Josip, (1951), Historija muzike. I dio, Školska knjiga, Zagreb.

15. Fjalor i mitologjisë, (1986), Biblioteka linguistike, Rilindja, Prishtinë.

16. Flaceliere, Robert, (1979), Grčka u doba Perikla. IKP, Naprijed, Zagreb 